\title{
The Role of Neighborhood Income Inequality in Adolescent Aggression and Violence
}

\section{Citation}

Pabayo, Roman, Beth E. Molnar, and Ichiro Kawachi. 2014. "The Role of Neighborhood Income Inequality in Adolescent Aggression and Violence." Journal of Adolescent Health 55 (4): 571-79. https://doi.org/10.1016/j.jadohealth.2014.04.012.

\section{Permanent link}

http://nrs.harvard.edu/urn-3:HUL.InstRepos:41275596

\section{Terms of Use}

This article was downloaded from Harvard University's DASH repository, WARNING: This file should NOT have been available for downloading from Harvard University's DASH repository.

\section{Share Your Story}

The Harvard community has made this article openly available.

Please share how this access benefits you. Submit a story.

\section{Accessibility}


Original article

\title{
The Role of Neighborhood Income Inequality in Adolescent Aggression and Violence
}

\author{
Roman Pabayo, Ph.D. ${ }^{\mathrm{a}, *}$, Beth E. Molnar, Sc.D. ${ }^{\mathrm{b}}$, and Ichiro Kawachi, M.D., Ph.D. ${ }^{\mathrm{a}}$ \\ a Department of Social and Behavioral Sciences, Harvard School of Public Health, Boston, Massachusetts \\ ${ }^{\mathrm{b}}$ Department of Health Sciences, Northeastern University, Bouvé College of Health Sciences, Boston, Massachusetts
}

Article history: Received December 22, 2013; Accepted April 16, 2014

Keywords: Income inequality; Aggression; Violence; Multilevel analysis; Socioeconomic factors; Neighborhood characteristics

\section{A B S T R A C T}

Purpose: Being a perpetrator or victim of assaults can have detrimental effects on the development and health of adolescents. Area-level income inequality has been suggested to be associated with crime and aggressive behavior. However, most prior research on this association has been ecological. Therefore, the purpose of this investigation was to describe the association between neighborhood-level income inequality and aggression and violence outcomes.

Methods: Data were collected from a sample of 1,878 adolescents living in 38 neighborhoods participating in the 2008 Boston Youth Survey. We used multilevel logistic regression models to estimate the association between neighborhood income inequality and attacking someone with a weapon, being attacked by someone with a weapon, being physically assaulted, being shown a gun by someone in the neighborhood, shot at by someone in the neighborhood, witnessing someone getting murdered in the past year, and having a close family member or friend murdered. Race and income inequality cross-level interactions were tested. Analyses were stratified by sex.

Results: Among nonblack boys, after adjusting for nativity, age, neighborhood-level income, crime, disorder, and proportion of the neighborhood that is black, income inequality was associated with an increased risk for committing acts of aggression and being a victim of violence. Among nonblack girls, those living in neighborhoods with high-income inequality were more likely to witness someone die a violent death in the previous year, in comparison to those in more equal neighborhoods.

Conclusions: Income inequality appears to be related to aggression and victimization outcomes among nonblack adolescents living in Boston.

(c) 2014 Society for Adolescent Health and Medicine. All rights reserved.

\section{IMPLICATIONS AND CONTRIBUTION}

Among nonblack adolescents, living in neighborhoods with high-income inequality is associated with an increased likelihood of experiencing aggression and violence outcomes, compared with those living in neighborhoods with low- or moderate-income inequality.
Aggressive acts and violent crimes such as assaults, shootings, and homicides have been consistently shown to have detrimental effects on children and youth and are therefore a public health concern [1,2]. Among children aged $2-17$ years in a U.S. national sample, more than one half had experienced a physical assault

Conflicts of Interest: R.P. is a Canadian Institutes of Health Research postdoctoral fellowship recipient. No financial disclosures were reported by the other authors of this article.

* Address correspondence to: Roman Pabayo, Ph.D., Department of Social and Behavioral Sciences, Harvard School of Public Health, 677 Huntington Avenue, Boston, MA 02115.

E-mail address: rpabayo@hsph.harvard.edu (R. Pabayo).
[3]. Only $29 \%$ reported experiencing no victimization of violence [3]. Recent evidence has identified associations between exposure to violence and adverse outcomes such as psychological distress, anxiety, and high blood pressure [4]. The consequences of stress can include maladaptive coping behaviors, such as smoking [5,6] and alcohol consumption [5-7], and marijuana use [6-9]. The burden of aggression and violence in the community is often concentrated in disadvantaged and predominantly minority schools and communities that are more likely to be racially and socioeconomically segregated in U.S. society $[10,11]$.

Environmental characteristics, such as the distribution of income in society, have also been hypothesized to influence 
aggressive and violent behavior [12-16]. For example, violent crime is thought of being a reflection of the quality of the social environment [14]. Violent crime rates, such as homicide, assault, and robbery, have been shown to be robustly associated with income inequality [14]. Income inequality has been shown to be associated with homicide rates among those aged 15-24 years [16]. With the exception of one study that identified higher levels of income inequality being associated with more frequent bullying among both males and females [17], most research that investigates the relationship between income inequality and aggression and violence outcomes has been ecological. As a result, findings might actually be spurious because of the ecological fallacy [14]. Ecological fallacy, or aggregation bias, has been defined as "the bias that may occur because an association observed between variables on an aggregate level does not necessarily represent the association that exists at an individual level" [18].

One mechanism proposed that might explain the relationship between income inequality and aggression is that when the gap between rich and poor within a society increases, this is accompanied by an erosion of social cohesion is thought to occur [15]. Lower social cohesion is in turn reflected by declining levels of trust in society, as well as the social exclusion of those who are left behind. According to Merton's social strain theory [19], when legitimate channels of upward social mobility are denied to individuals, they may seek alternate means of achieving social status and success, such as engaging in the illegal economy. This mechanism, combined with a sense of frustration and anomie, can find expression in increased acts of violence and aggression [14,15].

Previous research has indicated that there are gender differences in the likelihood of both being exposed to violence and being perpetuators of aggressive behavior [20,21]. Furthermore, researchers have observed that area-level socioeconomic characteristics might be related differently among males and females $[22,23]$. Therefore, females and males might react to income inequality in different ways.

The objective of this investigation was to examine the relationship among an ethnically diverse sample of urban youth, aged 13-19 years, attending high school, between neighborhood-level income inequality and aggressive and violent outcomes that include witnessing, perpetrating, and being a victim of violence. We also investigated whether neighborhoodlevel income inequality and aggression is explained by low social cohesion. This study improves on previous ecological studies of income inequality and aggression, which may be limited by the ecological fallacy.

\section{Methods}

For this investigation, we used data from the 2008 Boston Youth Survey (BYS), a biennial survey of high school students (grades 9-12) in Boston Public Schools, which have been described elsewhere [24,25]. Briefly, a two-stage, stratified, random-sampling strategy was used and has been described elsewhere $[25,26]$. First, we invited all 32 secondary schools in the Boston public school system. Twenty-two of the eligible schools agreed to participate. Second, these 22 schools then provided a list of classrooms stratified by grade, from which we randomly selected classrooms. The final sample of students was representative of students in Boston public high schools [26].
The BYS study staff developed the questionnaire, which covered topics such as health behaviors, indicators of positive youth development, with an emphasis on violence exposure [27]. The paper-and-pencil survey, which was pilot tested and which included a number of scales with demonstrated validity and reliability, was administered in classrooms in the spring of 2008 [27]. Opt-out consent was sought from students' parents before survey administration, that is, parents were asked to indicate if they did not want their children to participate in the BYS. The purpose of the survey was read aloud to the students by survey administrators, and at that time, students were also free to not fill out the survey if they did not wish to participate. Of the students selected ( $\mathrm{n}=2,725$ ), 69\% completed surveys ( $\mathrm{n}=$ 1,878). The office of Human Research Administration at the Harvard School of Public Health approved all procedures for the BYS.

\section{Study variables}

Seven aggression and exposure to violence outcome variables were used. Respondents were asked in the past 30 days if they had attacked someone with a weapon other than a gun, like a bat, bottle, chain or knife? Response options were Never, 1-2 times, 3 or more times, which were dichotomized to no versus yes. To determine if participants had been victimized, participants were asked: in the past 12 months, you got punched with a fist, kicked, choked, or beaten up by anybody; you got attacked or threatened with a weapon other than a gun, like a bat, bottle, chain, or knife; someone showed you they had a gun to scare you or get you to do something (do not include a toy gun); you were shot at or shot with a gun (do not include a toy gun); respectively. Response options were yes or no. Students were also asked about witnessing violence with the following items: if they had seen somebody get killed by violence like being shot, stabbed or beaten to death? Yes or no. Finally, students were asked about personal loss with the item: in your entire lifetime, have any close family friends of yours been killed by violence, like being shot, stabbed, or beaten to death? (Do not include those killed in war.) Response options were yes or no.

Covariates included in the study were students' age, nativity, (U.S. born, foreign born arrived $\leq 4$ years, and foreign born arrived $>4$ years), and race or ethnicity (black vs. nonblack).

Participants provided the nearest cross street of their residence for geocoding to U.S. Census tracts. Data from the U.S. Census American Community Survey in 2008 were used to characterize neighborhood clusters of Census tracts; these neighborhood clusters were formed by working with key informants from across the city of Boston to identify 38 socially meaningful neighborhood clusters. A socioeconomic score, economic deprivation, was created using principal component analysis. A higher score was indicative of greater economic deprivation. U.S. Census indicators included in this score were the proportion of residents living below poverty level, proportion of households receiving public assistance, and proportion of families with a female head of household (Cronbach alpha $=.84)$. Tertiles of the neighborhood economic deprivation score were used to categorize neighborhood-level economic deprivation into low, moderate, and high. The proportion of the residential neighborhood that is black was categorized into low (<33\%), moderate $(33 \%-66 \%)$, and high (>66\%) as well. 
Table 1

Sociodemographic characteristics of adolescents $(n=1443)$ and neighborhoods $(\mathrm{n}=37)$ participating in the Boston Youth Study

\begin{tabular}{|c|c|c|}
\hline Characteristic & $\mathrm{n}$ & Proportion (\%) \\
\hline \multicolumn{3}{|l|}{ Sex } \\
\hline Male & 652 & 45.2 \\
\hline Female & 791 & 54.8 \\
\hline \multicolumn{3}{|l|}{ Race } \\
\hline Black & 688 & 47.7 \\
\hline White & 156 & 10.8 \\
\hline Asian or South Asian & 121 & 8.4 \\
\hline Hispanic & 373 & 25.9 \\
\hline Other & 105 & 7.3 \\
\hline \multicolumn{3}{|l|}{ Nativity } \\
\hline New immigrant & 136 & 9.4 \\
\hline Settled immigrant & 286 & 19.8 \\
\hline Born in the United States & 1021 & 70.8 \\
\hline \multicolumn{3}{|l|}{ Age, years } \\
\hline 13 or 14 & 118 & 8.2 \\
\hline 15 & 286 & 19.8 \\
\hline 16 & 398 & 27.6 \\
\hline 17 & 277 & 26.1 \\
\hline 18 & 201 & 13.9 \\
\hline 19 & 63 & 4.4 \\
\hline Neighborhood features & Mean (standard deviation) & Range \\
\hline Gini Score & $.46(.06)$ & .28 to .59 \\
\hline Economic deprivation & $.02(1.01)$ & -1.79 to 2.42 \\
\hline Danger & $.01(1.10)$ & -1.17 to 3.46 \\
\hline Disorder & $2.87(.49)$ & 2.06 to 3.98 \\
\hline Proportion black (\%) & $37.8(28.1)$ & 1.8 to 92.5 \\
\hline
\end{tabular}

To assess student perception of social cohesion of their neighborhood, five statements, which have been used previously [28], were administered in the BYS. The five items included: (1) I live in a neighborhood where people know and like each other; (2) People in my neighborhood are willing to help their neighbors; (3) People in my neighborhood generally get along with each other; (4) People in my neighborhood generally share the same beliefs about what is right and wrong; and (5) People in my neighborhood can be trusted. Response options included (1) strongly disagree; (2) disagree; (3) agree; and (4) strongly agree. The average social cohesion score was 12.0 (standard deviation $[S D]=2.9$ ) and the range was 5-20. Tertile cutoffs were used to categorize social cohesion into low, moderate, and high.

To assess neighborhood disorder, we used the data collected from the Boston Neighborhood Study (BNS), which has been described elsewhere [26,29]. Briefly, the BNS is a survey of approximately 1,710 Boston adults aged $\geq 18$ years administered in 2008. Information from the BNS was used to supplement the BYS data with contextual information about neighborhood-level conditions and social processes perceived by adult residents [26]. Disorder is a neighborhood exposure that is composed of both social (i.e., presence or absence of drinking alcohol in public) and physical disorders (i.e., abandoned cars). A combined score was created; a greater score is indicative of greater neighborhood disorder. Tertiles were used to categorize neighborhoods into low, moderate, and high neighborhood disorder.

To measure neighborhood danger, counts of criminal homicide, robbery, aggravated assault, burglary, larceny theft, vehicle theft, and arson were added using data from the Boston Police Department, and matched to U.S. Census tracts. The higher the score, the greater the danger is within the neighborhood. Tertiles were used to categorize danger within the neighborhood into low, moderate, and high.

\section{Neighborhood inequality}

To measure inequality, we used the Gini coefficient, which has a range of 0 (perfect equality, every household in the neighborhood has the exact same income) to 1.0 (perfect inequality, where households earn a wide range of incomes). The calculation of the Gini coefficient has been provided elsewhere [13]. Briefly, the Gini coefficient is based on the Lorenz curve, a cumulative frequency curve that compares the distribution of a specific variable with the uniform distribution that represents equality. In the current analysis, the Gini coefficient was calculated for each census tract by the Boston Indicators Project (http://www. bostonindicators.org/). The Gini coefficient was then matched to each census tract participating in the BYS. The average Gini coefficient was then calculated using the values of the census tracts in 37 of the 38 BYS neighborhoods. The Gini coefficient was not available for one of the neighborhoods. The 75th percentile was used as a threshold to categorize the neighborhoods into high-income inequality neighborhoods versus low- or moderateincome inequality neighborhoods. In addition, we repeated the previously mentioned analyses using a z-transformed Gini coefficient to examine the association between a continuous measure of neighborhood inequality and the aggression and violence outcomes.

\section{Statistical analysis}

Because we wanted to study neighborhood-level inequality as a predictor of individual-level violence experiences, we used multilevel modeling with students nested within neighborhood clusters. Multilevel models are a generalization of the linear model used in traditional analysis. Further information regarding the use of this type of analysis in public health research is available [30]. Multilevel logistic regression was used for each of the dichotomous outcomes. Also, analyses were stratified by sex.

To investigate the potential effect of income inequality on aggression and violence outcomes, a step-up approach was conducted, yielding different sets of analyses. First, a set of analyses involved estimating the null model. For each dichotomous outcome, the null model is used to determine the 95\% plausible value range, which is an indication of the variability of the likelihood of experiencing each outcome. Then individual- and neighborhood-level characteristics were then added to the models (model 1). Cross-level race-income inequality and gender-income inequality interactions were then added to determine if income inequality had a differential effect across different racial groups (model 2) and by gender (not shown). These two cross-level interactions were significant. We decided to stratify the results by sex and keep the race-income inequality cross-level interaction term in the models. Finally, student reported social cohesion was included to test for mediation but was not found to be a significant mediator. The previously mentioned analyses were repeated using the z-transformed Gini coefficient. Because consistent findings were obtained, the results using the dichotomized Gini coefficient were used to facilitate interpretation.

To determine whether social cohesion acted as mediators between income inequality and the aggression and violence outcomes, we applied the Baron and Kenny [31] method to test for mediation. More specifically, the following relationships were tested: (1) income inequality and each of the outcomes; 
Table 2

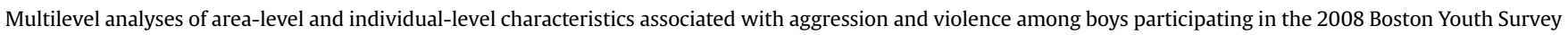
$(\mathrm{n}=652)$

\begin{tabular}{|c|c|c|c|c|c|c|c|}
\hline \multirow[t]{2}{*}{ Covariate } & \multicolumn{2}{|c|}{$\begin{array}{l}\text { Attacked someone in the } \\
\text { neighborhood }\end{array}$} & \multicolumn{2}{|c|}{$\begin{array}{l}\text { Beaten by someone in the } \\
\text { neighborhood }\end{array}$} & \multicolumn{2}{|c|}{$\begin{array}{l}\text { Was attacked in the neighborhood } \\
\text { with a weapon }\end{array}$} & \multirow{2}{*}{$\begin{array}{l}\text { Shown gun by } \\
\text { someone in } \\
\text { neighborhood } \\
\text { Model 1, OR } \\
\text { (95\% CI) }\end{array}$} \\
\hline & $\begin{array}{l}\text { Model 1, OR } \\
(95 \% \mathrm{CI})\end{array}$ & $\begin{array}{l}\text { Model 2, OR } \\
(95 \% \mathrm{CI})\end{array}$ & $\begin{array}{l}\text { Model 1, OR } \\
(95 \% \mathrm{CI})\end{array}$ & $\begin{array}{l}\text { Model 2, OR } \\
(95 \% \mathrm{CI})\end{array}$ & $\begin{array}{l}\text { Model 1, OR } \\
(95 \% \mathrm{CI})\end{array}$ & $\begin{array}{l}\text { Model 2, OR } \\
(95 \% \mathrm{CI})\end{array}$ & \\
\hline \multicolumn{8}{|l|}{$\begin{array}{l}\text { Area-level covariates } \\
\text { Income inequality }\end{array}$} \\
\hline Low or moderate (reference) & 1.00 & 1.00 & 1.00 & 1.00 & 1.00 & 1.00 & 1.00 \\
\hline High Gini ( $>75$ th percentile) & $1.12(.65-1.95)$ & $2.48(1.23-5.02)$ & $1.37(1.00-1.88)$ & $1.05(.61-1.82)$ & $1.61(.68-3.83)$ & $2.87(1.04-7.88)$ & $1.86(1.08-3.23)$ \\
\hline \multicolumn{8}{|l|}{ Economic deprivation } \\
\hline Low (reference) & 1.00 & 1.00 & 1.00 & 1.00 & 1.00 & 1.00 & 1.00 \\
\hline Moderate & $1.41(.68-2.90)$ & $1.38(.69-2.75)$ & $1.13(.78-1.65)$ & $1.13(.76-1.67)$ & $1.57(.53-4.68)$ & $1.60(.67-3.81)$ & $.84(.46-1.53)$ \\
\hline High & $.84(.49-1.44)$ & $.77(.46-1.29)$ & $.76(.43-1.33)$ & $.78(.44-1.39)$ & $.48(.14-1.61)$ & $.45(.20-1.00)$ & $.51(.24-1.08)$ \\
\hline \multicolumn{8}{|l|}{ Danger } \\
\hline Low (reference) & 1.00 & 1.00 & 1.00 & 1.00 & 1.00 & 1.00 & 1.00 \\
\hline Moderate & $1.13(.56-2.28)$ & $1.21(.60-2.45)$ & $1.04(.54-1.99)$ & $1.02(.53-1.99)$ & $1.50(.45-5.03)$ & $1.54(.79-3.02)$ & $1.43(.57-3.60)$ \\
\hline High & $1.35(.70-2.59)$ & $1.43(.78-2.63)$ & $.83(.54-1.29)$ & $.82(.53-1.27)$ & $1.31(.45-3.84)$ & $1.32(.64-2.70)$ & $1.12(.45-2.77)$ \\
\hline \multicolumn{8}{|l|}{ Disorder } \\
\hline Low (reference) & 1.00 & 1.00 & 1.00 & 1.00 & 1.00 & 1.00 & 1.00 \\
\hline Moderate & $1.25(.75-2.08)$ & $1.16(.72-1.89)$ & $.90(.59-1.38)$ & $.93(.60-1.44)$ & $1.36(.44-4.15)$ & $1.27(.64-2.52)$ & $1.2(.62-2.31)$ \\
\hline High & $.87(.45-1.68)$ & $.82(.40-1.67)$ & $.62(.29-1.34)$ & $.63(.29-1.40)$ & $.63(.15-2.59)$ & $.59(.24-1.47)$ & $.80(.30-2.14)$ \\
\hline \multicolumn{8}{|l|}{ Proportion black } \\
\hline Low (reference) & 1.00 & 1.00 & 1.00 & 1.00 & 1.00 & 1.00 & 1.00 \\
\hline Medium & $1.19(.60-2.37)$ & $1.06(.50-2.28)$ & $.92(.56-1.52)$ & $.95(.58-1.56)$ & $1.44(.48-4.37)$ & $1.35(.45-4.03)$ & $1.55(.61-3.90)$ \\
\hline High & $1.59(.81-3.13)$ & $1.56(.78-3.11)$ & $1.35(.77-2.37)$ & $1.34(.76-2.38)$ & $1.77(.52-6.05)$ & $1.76(.62-5.01)$ & $.89(.35-2.28)$ \\
\hline \multicolumn{8}{|l|}{ Individual-level covariates } \\
\hline \multicolumn{8}{|l|}{ Race } \\
\hline Nonblack (reference) & 1.00 & 1.00 & 1.00 & 1.00 & 1.00 & 1.00 & 1.00 \\
\hline Black & $1.11(.69-1.79)$ & $1.67(.95-2.96)$ & $.55(.38-0.81)$ & $.48(.32-0.71)$ & $.84(.51-1.38)$ & $1.22(.67-2.23)$ & $1.61(.90-2.88)$ \\
\hline Black ( $>75$ th percentile) & & $.18(.08-0.42)$ & & $1.78(.82-3.91)$ & & $.25(.09-0.73)$ & \\
\hline Nativity (reference U.S. born) & 1.00 & 1.00 & 1.00 & 1.00 & 1.00 & 1.00 & 1.00 \\
\hline Moved to U.S. $\geq 5$ years & $.69(.40-1.19)$ & $.68(.38-1.19)$ & $1.48(.85-2.55)$ & $1.49(.86-2.58)$ & $1.74(1.07-2.82)$ & $1.74(1.04-1.69)$ & $1.53(.83-2.84)$ \\
\hline Moved to U.S. $<5$ years & $.28(.10-0.74)$ & $.24(.09-0.69)$ & $1.12(.50-2.48)$ & $1.16(.52-2.59)$ & $1.02(.48-2.15)$ & $.93(.51-1.69)$ & $1.08(.48-2.44)$ \\
\hline \multicolumn{8}{|l|}{ Age, years } \\
\hline 14 (reference) & 1.00 & 1.00 & 1.00 & 1.00 & 1.00 & 1.00 & 1.00 \\
\hline 15 & $.45(.16-1.31)$ & $.50(.17-1.49)$ & $.90(.38-2.11)$ & $.87(.37-2.02)$ & $.91(.37-2.23)$ & $1.03(.48-2.18)$ & $.73(.34-1.55)$ \\
\hline 16 & $.83(.37-1.83)$ & $.92(.41-2.09)$ & $2.16(.81-5.80)$ & $2.09(.78-5.56)$ & $1.05(.46-2.39)$ & $1.15(.54-2.43)$ & $.89(.36-2.19)$ \\
\hline 17 & $.85(.37-1.94)$ & $.92(.39-2.16)$ & $1.36(.58-3.17)$ & $1.32(.57-3.04)$ & $1.01(.44-2.35)$ & $1.10(.56-2.17)$ & $.92(.36-2.36)$ \\
\hline 18 & $.72(.23-2.23)$ & $.81(.25-2.60)$ & $.97(.30-3.13)$ & $.93(.29-2.95)$ & $.67(.25-1.78)$ & $.76(.38-1.54)$ & $.72(.25-2.08)$ \\
\hline 19 & $1.53(.48-4.88)$ & $1.60(.47-5.42)$ & $1.14(.32-4.05)$ & $1.14(.33-4.01)$ & $1.40(.45-4.40)$ & $1.41(.64-3.11)$ & $2.01(.59-6.79)$ \\
\hline
\end{tabular}

(2) income inequality and social cohesion; and (3) social cohesion and each of the seven outcomes.

\section{Results}

Characteristics of the 1,443 students attending secondary schools in the Boston area are summarized in Table 1. Overall, the sample had slightly more females (54.8\%), almost half were black (47.7\%), and a majority was born in the United States (70.8\%). Prevalence of violence experiences ranged from $6 \%$, who had been shown a gun, to $47 \%$, who had someone close to them die as a result of violence.

A summary of the neighborhood characteristics can be found in Table 1. For example, the average Gini score across all neighborhoods was $.46(\mathrm{SD}=.06)$ and the range was $.28-.59$. The average proportion of the population that was black within the neighborhood clusters was $37.8 \%(\mathrm{SD}=28.1)$ and the range was 1.8\%-92.5\%.

Among boys, the 95\% plausible value ranges determined from the null models showed some variation across neighborhoods concerning the outcomes: attacked someone with a weapon (12.7\%-14.0\%), been assaulted (19.0\%-19.4\%), been attacked by someone using a weapon $(12.7 \%-14.0 \%)$, been shown a gun (5.0\%-22.2\%), had witnessed a violent death $(14.0 \%-21.4 \%)$, and had someone close been murdered (24.6\%-65.9\%). Among girls, the $95 \%$ plausible value ranges also indicated some variation across neighborhoods concerning the outcomes attacked someone with a weapon $(7.1 \%-7.6 \%)$, been assaulted $(9.4 \%-11.6 \%)$, been attacked using a weapon (2.6\%-11.5\%), been shown a gun (1.5\%-7.4\%), had witnessed a violent death $(9.1 \%-33.2 \%)$, and had a family member or friend murdered (25.6\%-74.8\%).

When potential individual- and neighborhood-level confounders were added to the models, among boys, those living in the most unequal neighborhoods were more likely to have been assaulted by someone in the neighborhood (odds ratio [OR] = $1.37,95 \%$ confidence interval $[\mathrm{CI}]=1.00-1.88$ ), to have been shown a gun by someone in the neighborhood ( $\mathrm{OR}=1.86,95 \%$ $\mathrm{CI}=1.08-3.23$ ), or to have had a close family member or friend been murdered $(\mathrm{OR}=1.77,95 \% \mathrm{CI}=1.27-2.46)$ in comparison to those living in more equal neighborhoods (models 1 , Table 2). No significant findings were observed among girls.

When race and neighborhood inequality cross-level effects were tested, the association of income inequality with the aggression and violence outcomes varied significantly across 
Table 2

Continued

\begin{tabular}{|c|c|c|c|c|c|c|}
\hline \multirow{2}{*}{$\begin{array}{l}\text { Shown gun by } \\
\text { someone in } \\
\text { neighborhood } \\
\text { Model 2, OR } \\
(95 \% \mathrm{CI})\end{array}$} & \multicolumn{2}{|c|}{$\begin{array}{l}\text { Shot at by someone in the } \\
\text { neighborhood }\end{array}$} & \multicolumn{2}{|c|}{$\begin{array}{l}\text { Witnessed a violent death in the } \\
\text { previous year }\end{array}$} & \multicolumn{2}{|c|}{$\begin{array}{l}\text { Close family member or friend } \\
\text { has been murdered }\end{array}$} \\
\hline & $\begin{array}{l}\text { Model 1, OR } \\
(95 \% \mathrm{CI})\end{array}$ & $\begin{array}{l}\text { Model 2, OR } \\
(95 \% \mathrm{CI})\end{array}$ & $\begin{array}{l}\text { Model } 1, \text { OR } \\
(95 \% \mathrm{CI})\end{array}$ & $\begin{array}{l}\text { Model 2, OR } \\
(95 \% \mathrm{CI})\end{array}$ & $\begin{array}{l}\text { Model 1, OR } \\
(95 \% \mathrm{CI})\end{array}$ & $\begin{array}{l}\text { Model 2, OR } \\
(95 \% \mathrm{CI})\end{array}$ \\
\hline \multicolumn{7}{|c|}{$\begin{array}{l}\text { Area-level covariates } \\
\text { Income inequality }\end{array}$} \\
\hline 1.00 & 1.00 & 1.00 & 1.00 & 1.00 & 1.00 & 1.00 \\
\hline $3.27(1.30-8.24)$ & $1.45(.77-2.74)$ & $2.72(1.12-6.58)$ & $1.02(.56-1.85)$ & $1.53(.79-2.97)$ & $1.77(1.27-2.46)$ & $2.33(1.12-4.84)$ \\
\hline \multicolumn{7}{|c|}{ Economic deprivation } \\
\hline 1.00 & 1.00 & 1.00 & 1.00 & 1.00 & 1.00 & 1.00 \\
\hline $.85(.45-1.60)$ & $1.65(.68-3.98)$ & $1.56(.66-3.70)$ & $.96(.52-1.78)$ & $.96(.52-1.80)$ & $.85(.53-1.36)$ & $.85(.53-1.35)$ \\
\hline $\begin{array}{l}.48(.23-1.00) \\
\text { Danger }\end{array}$ & $1.17(.41-3.37)$ & $1.05(.38-2.89)$ & $.86(.50-1.48)$ & $.81(.46-1.41)$ & $1.02(.56-1.83)$ & $.98(.55-1.75)$ \\
\hline 1.00 & 1.00 & 1.00 & 1.00 & 1.00 & 1.00 & 1.00 \\
\hline $1.44(.58-3.59)$ & $.79(.27-2.34)$ & $.85(.29-2.52)$ & $2.01(1.07-3.81)$ & $2.06(1.07-3.96)$ & $1.10(.65-1.85)$ & $1.10(.66-1.85)$ \\
\hline $\begin{array}{l}1.11(.46-2.72) \\
\quad \text { Disorder }\end{array}$ & $.70(.26-1.90)$ & $.74(.28-2.00)$ & $1.77(.94-3.33)$ & $1.80(.96-3.41)$ & $.93(.52-1.68)$ & $.94(.53-1.68)$ \\
\hline 1.00 & 1.00 & 1.00 & 1.00 & 1.00 & 1.00 & 1.00 \\
\hline $1.14(.59-2.22)$ & $1.66(.67-4.14)$ & $1.51(.63-3.62)$ & $.90(.55-1.47)$ & $.87(.54-1.41)$ & $1.39(.79-2.46)$ & $1.37(.79-2.39)$ \\
\hline $\begin{array}{l}.77(.29-2.07) \\
\text { Proportion blacl }\end{array}$ & $1.06(.35-3.17)$ & $1.02(.33-3.10)$ & $.79(.39-1.62)$ & $.77(.37-1.60)$ & $1.33(.79-2.23)$ & $1.31(.78-2.19)$ \\
\hline 1.00 & 1.00 & 1.00 & 1.00 & 1.00 & 1.00 & 1.00 \\
\hline $1.42(.56-3.62)$ & $1.22(.44-3.42)$ & $1.11(.37-3.43)$ & $2.00(.96-4.14)$ & $1.92(.91-4.06)$ & $1.49(.91-2.43)$ & $1.46(.89-2.38)$ \\
\hline $.88(.34-2.26)$ & $1.60(.60-4.29)$ & $1.57(.56-4.36)$ & $2.34(1.05-5.22)$ & $2.40(1.04-5.53)$ & $1.72(1.09-2.73)$ & $1.74(1.10-2.75)$ \\
\hline \multicolumn{7}{|c|}{$\begin{array}{l}\text { Individual-level covariates } \\
\text { Race }\end{array}$} \\
\hline 1.00 & 1.00 & 1.00 & 1.00 & 1.00 & 1.00 & 1.00 \\
\hline $2.22(1.14-4.35)$ & $.53(.28-1.01)$ & $.82(.36-1.86)$ & $.89(.59-1.35)$ & $1.07(.67-1.70)$ & $1.20(.81-1.78)$ & $1.34(.90-2.01)$ \\
\hline $.32(.10-1.00)$ & & $.18(.05-0.73)$ & & $.43(.21-0.87)$ & $.35(.17-0.73)$ & $.59(.23-1.48)$ \\
\hline 1.00 & 1.00 & 1.00 & 1.00 & 1.00 & 1.00 & 1.00 \\
\hline $1.51(.82-2.79)$ & $1.17(.68-2.03)$ & $1.16(.66-2.03)$ & $1.06(.60-1.86)$ & $1.05(.60-1.83)$ & $.71(.40-1.26)$ & $.71(.40-1.25)$ \\
\hline $\begin{array}{l}.99(.43-2.30) \\
\text { Age, years }\end{array}$ & $.42(.15-1.17)$ & $.36(.12-1.13)$ & $.54(.23-1.28)$ & $.51(.21-1.20)$ & $.35(.17-0.73)$ & $.34(.16-0.72)$ \\
\hline 1.00 & 1.00 & 1.00 & 1.00 & 1.00 & 1.00 & 1.00 \\
\hline $.80(.35-1.84)$ & $1.17(.30-4.61)$ & $1.34(.32-5.61)$ & $1.44(.50-4.14)$ & $1.51(.54-4.26)$ & $1.25(.62-2.53)$ & $1.29(.64-2.61)$ \\
\hline $.97(.38-2.48)$ & $2.69(.83-8.68)$ & $3.03(.89-10.32)$ & $1.77(.57-5.54)$ & $1.87(.61-5.79)$ & $.97(.49-1.94)$ & $1.01(.51-2.01)$ \\
\hline $1.00(.38-2.65)$ & $2.55(.86-7.57)$ & $2.86(.90-9.03)$ & $1.84(.56-6.01)$ & $1.93(.60-6.19)$ & $1.29(.60-2.78)$ & $1.33(.62-2.86)$ \\
\hline $.80(.27-2.36)$ & $2.20(.53-9.04)$ & $2.58(.58-11.56)$ & $1.57(.41-6.03)$ & $1.69(.44-6.43)$ & $1.01(.44-2.33)$ & $1.06(.46-2.43)$ \\
\hline $2.06(.59-7.19)$ & $9.21(2.70-31.43)$ & $9.75(2.61-36.39)$ & $4.04(1.00-16.30)$ & $4.13(1.04-16.42)$ & $1.65(.78-3.50)$ & $1.67(.79-3.53)$ \\
\hline
\end{tabular}

$\mathrm{CI}=$ confidence interval; $\mathrm{OR}=$ odds ratio.

racial groups. The odds of violent experiences for nonblack boys in the most unequal neighborhoods ranged from 2.3 (close friend was killed by violence) to 3.3 (shown a gun; models 2 , Table 2). In contrast, the odds of violent experiences for black boys in the most unequal neighborhoods ranged from .18 (attacked by someone in the neighborhood) to .43 (witness someone die a violent death in the past year; models 2, Table 2).

Among nonblack girls, those living in the most unequal neighborhoods were more likely to witness a violent death $(\mathrm{OR}=$ $1.64,95 \% \mathrm{CI}=1.11-2.42$ ), in comparison to those living in the most equal neighborhoods (models 2, Table 3 ). However, black girls living in the most unequal neighborhoods were significantly less likely to witness a violent death $(\mathrm{OR}=.58,95 \% \mathrm{CI}=.33,0.99$; models 2, Table 3).

When social cohesion was tested as a possible mediator between income inequality and the outcomes, the risk estimates were not changed (results not shown). Therefore, social cohesion appears to not be along the pathway between income inequality and the aggression and violence outcomes. This finding was also confirmed when the Baron and Kenny method to test for mediation. Income inequality was not associated with student reported social cohesion among boys and girls (Table 4).

\section{Discussion}

This present investigation is one of the first to investigate the association between neighborhood-level income inequality and aggression and violence in a sample of adolescents living in Boston, MA. We observed significant findings among nonblack boys that indicated those living in high-income inequality neighborhoods were more likely to commit acts of aggression or to be victims of violence, in comparison to nonblack boys in more equal neighborhoods. Among nonblack girls, those living in unequal neighborhoods were more likely to have witnessed someone die a violent death in the previous year in comparison to those living in more equal neighborhoods. However, neighborhood inequality worked in the opposite direction for these aggression and violence outcomes among black youth, findings that we did not expect. Overall, findings indicate that neighborhood income inequality is differentially associated with aggression and violence outcomes across racial groups and gender. Social, cultural, and economic factors might be involved that either amplify or assuage the potential influence of income inequality across racial groups. 
Table 3

Multilevel analyses of area-level and individual-level characteristics associated with aggression and violence among girls participating in the 2008 Boston Youth Survey $(\mathrm{n}=791)$

\begin{tabular}{|c|c|c|c|c|c|c|c|}
\hline \multirow[t]{2}{*}{ Covariate } & \multicolumn{2}{|c|}{$\begin{array}{l}\text { Attacked someone in the } \\
\text { neighborhood }\end{array}$} & \multicolumn{2}{|c|}{$\begin{array}{l}\text { Beaten by someone in the } \\
\text { neighborhood }\end{array}$} & \multicolumn{2}{|c|}{$\begin{array}{l}\text { Was attacked in the } \\
\text { neighborhood with a weapon }\end{array}$} & \multirow{2}{*}{$\begin{array}{l}\text { Shown gun by } \\
\text { someone in } \\
\text { neighborhood } \\
\text { Model 1, OR } \\
(95 \% \mathrm{CI})\end{array}$} \\
\hline & $\begin{array}{l}\text { Model 1, OR } \\
(95 \% \mathrm{CI})\end{array}$ & $\begin{array}{l}\text { Model 2, OR } \\
(95 \% \mathrm{CI})\end{array}$ & $\begin{array}{l}\text { Model 1, OR } \\
(95 \% \mathrm{CI})\end{array}$ & $\begin{array}{l}\text { Model 2, OR } \\
(95 \% \mathrm{CI})\end{array}$ & $\begin{array}{l}\text { Model 1, OR } \\
(95 \% \mathrm{CI})\end{array}$ & $\begin{array}{l}\text { Model 2, OR } \\
(95 \% \mathrm{CI})\end{array}$ & \\
\hline \multicolumn{8}{|l|}{ Area-level covariates } \\
\hline \multicolumn{8}{|l|}{ Income inequality } \\
\hline Low or moderate (reference) & 1.00 & 1.00 & 1.00 & 1.00 & 1.00 & 1.00 & 1.00 \\
\hline High Gini (>75th percentile) & $1.33(.85-2.08)$ & $1.65(.69-3.93)$ & $.62(.36-1.07)$ & $.52(.20-1.36)$ & $.90(.42-1.93)$ & $1.06(.47-2.40)$ & $.63(.31-1.29)$ \\
\hline \multicolumn{8}{|l|}{ Economic deprivation } \\
\hline Low (reference) & 1.00 & 1.00 & 1.00 & 1.00 & 1.00 & 1.00 & 1.00 \\
\hline Moderate & $.50(.18-1.38)$ & $.50(.18-1.40)$ & $1.45(.57-3.70)$ & $1.44(.60-3.48)$ & $.54(.13-2.30)$ & $.55(.13-2.36)$ & $.26(.09-0.70)$ \\
\hline High & $1.08(.40-2.93)$ & $1.08(.40-2.95)$ & $1.24(.50-3.06)$ & $1.23(.49-3.11)$ & $1.24(.45-3.37)$ & $1.23(.45-3.36)$ & $.44(.16-1.24)$ \\
\hline \multicolumn{8}{|l|}{ Danger } \\
\hline Low (reference) & 1.00 & 1.00 & 1.00 & 1.00 & 1.00 & 1.00 & 1.00 \\
\hline Moderate & $1.20(.55-2.65)$ & $1.21(.55-2.69)$ & $1.15(.57-2.32)$ & $1.15(.47-2.80)$ & $.61(.27-1.38)$ & $.61(.27-1.38)$ & $1.01(.36-2.85)$ \\
\hline High & $1.26(.54-2.95)$ & $1.27(.55-2.96)$ & $1.78(.95-3.36)$ & $1.78(.79-4.01)$ & $.78(.44-1.41)$ & $.79(.44-1.41)$ & $.94(.29-3.01)$ \\
\hline \multicolumn{8}{|l|}{ Disorder } \\
\hline Low (reference) & 1.00 & 1.00 & 1.00 & 1.00 & 1.00 & 1.00 & 1.00 \\
\hline Moderate & $.67(.25-1.79)$ & $.67(.25-1.82)$ & $.70(.23-2.11)$ & $.70(.28-1.77)$ & $.82(.13-5.24)$ & $.82(.13-5.31)$ & $.82(.25-2.64)$ \\
\hline High & $.93(.30-2.89)$ & $.90(.29-2.84)$ & $.50(.16-1.59)$ & $.50(.16-1.60)$ & $1.29(.26-6.39)$ & $1.26(.25-6.30)$ & $2.02(.70-5.85)$ \\
\hline \multicolumn{8}{|l|}{ Proportion black } \\
\hline Low (reference) & 1.00 & 1.00 & 1.00 & 1.00 & 1.00 & 1.00 & 1.00 \\
\hline Medium & $1.00(.38-2.63)$ & $.99(.38-2.62)$ & $1.57(.79-3.11)$ & $1.58(.67-3.72)$ & $.83(.30-2.31)$ & $.82(.29-2.33)$ & $2.20(.51-9.59)$ \\
\hline High & $1.11(.41-3.03)$ & $1.10(.40-3.01)$ & $1.42(.59-3.40)$ & $1.43(.53-3.90)$ & $1.15(.27-5.03)$ & $1.13(.26-4.99)$ & $5.79(1.13-29.72)$ \\
\hline \multicolumn{8}{|l|}{ Individual-level covariates } \\
\hline \multicolumn{8}{|l|}{ Race } \\
\hline Nonblack (reference) & 1.00 & 1.00 & 1.00 & 1.00 & 1.00 & 1.00 & 1.00 \\
\hline Black & $2.32(1.38-3.94)$ & $2.60(1.44-4.71)$ & $1.00(.68-1.45)$ & $.93(.52-1.65)$ & $.59(.32-1.08)$ & $.66(.32-1.36)$ & $.44(.24-0.84)$ \\
\hline Black (>75th percentile) & & $.71(.28-1.80)$ & & $1.38(.43-4.42)$ & & $.62(.20-1.93)$ & \\
\hline Nativity (reference U.S. born) & 1.00 & 1.00 & 1.00 & 1.00 & 1.00 & 1.00 & 1.00 \\
\hline Moved to U.S. $\geq 5$ years & $.90(.42-1.96)$ & $.91(.42-1.97)$ & $.79(.41-1.53)$ & $.79(.43-1.47)$ & $1.02(.56-1.88)$ & $1.03(.57-1.88)$ & $.92(.45-1.91)$ \\
\hline Moved to U.S. $<5$ years & $.30(.04-2.50)$ & $.30(.04-2.49)$ & $.53(.15-1.82)$ & $.53(.18-1.58)$ & $1.52(.57-4.08)$ & $1.52(.57-4.06)$ & $1.31(.37-4.58)$ \\
\hline \multicolumn{8}{|l|}{ Age, years } \\
\hline 14 (reference) & 1.00 & 1.00 & 1.00 & 1.00 & 1.00 & 1.00 & 1.00 \\
\hline 15 & $.73(.29-1.81)$ & $.73(.29-1.82)$ & $2.30(.81-6.58)$ & $2.30(.80-6.63)$ & $.74(.27-2.01)$ & $.75(.27-2.06)$ & $3.12(.68-14.22)$ \\
\hline 16 & $.35(.14-0.91)$ & $.35(.13-0.91)$ & $1.62(.52-4.99)$ & $1.62(.52-5.04)$ & $.51(.19-1.36)$ & $.52(.20-1.36)$ & $.83(.15-4.72)$ \\
\hline 17 & $.38(.15-0.95)$ & $.38(.15-0.96)$ & $2.71(.95-7.73)$ & $2.71(.90-8.12)$ & $.45(.19-1.10)$ & $.46(.19-1.11)$ & $1.82(.49-6.76)$ \\
\hline 18 & $.26(.12-0.56)$ & $.26(.12-0.57)$ & $1.67(.53-5.23)$ & $1.66(.50-5.59)$ & $.49(.17-1.42)$ & $.49(.17-1.41)$ & $2.96(.54-16.28)$ \\
\hline 19 & $1.15(.27-4.81)$ & $1.12(.26-4.85)$ & $1.53(.24-9.62)$ & $1.57(.26-9.60)$ & $.79(.16-3.89)$ & $.76(.16-3.64)$ & $5.73(.54-61.20)$ \\
\hline
\end{tabular}

The distribution of income in a society has been theorized to be associated with aggression and violence. Several mechanisms for this association have been proposed. First, societies with higher levels of income inequality might lead to stressful comparisons, that is, a growing sense of relative deprivation [15]. These invidious social comparisons can potentially intensify feelings of competition within society, making one's status, more important compared with more egalitarian societies [32]. Feelings of anger and frustration might also intensify because of lack of access to resources and status [32]. Like adults, adolescents might also be aware of their status, which might foster a social environment that leads to social isolation and therefore to aggression [17].

Furthermore, high inequality might not only negatively affect people from low socioeconomic backgrounds. Those from high socioeconomic backgrounds might also experience the detrimental effects of income inequality. For example, social cohesion and trust are also eroded among the wealthier residents of unequal neighborhoods. This might lead to feelings of fear and insecurity, which are associated with aggression and violence $[14,15]$. Wealthier residents might feel that they have to arm themselves for protection from their poorer neighbors.

Another mechanism that might explain how income inequality is related to aggression is that high-income inequality erodes social cohesion. When the gap between the wealthy and poor widens, the "glue" between individuals is eroded, which can also lead to growing mistrust between individuals [15]. The lack of trust between members of society has been shown to partly account for the association between income inequality and aggression [15]. However, our findings indicate that social cohesion does not act as a mediator between income inequality and aggression in this study. One explanation for this finding is that the study design was cross sectional. Longitudinal analyses would allow us to fully test the hypothesis that social cohesion mediates the relationship between income inequality and aggression and violence. It is also possible that social cohesion might be more important for adults than adolescents with regards to the potential influence of income inequality on aggression and violence.

Among nonblack youth, our results also indicate that the association between income inequality and aggression is more evident among boys in comparison to girls. This variance might be due the different ways in which boys and girls cope to the stress generated from income inequality. To cope with stressful situations, girls have been socialized to seek social support $[33,34]$. On the contrary, boys are more likely to seek tasksupported activities to cope with stress [35]. Task-oriented strategies involve taking direct action to alter the situation to 
Table 3

Continued

\begin{tabular}{|c|c|c|c|c|c|c|}
\hline \multirow{2}{*}{$\begin{array}{l}\text { Shown gun by } \\
\text { someone in } \\
\text { neighborhood } \\
\text { Model 2, OR } \\
(95 \% \mathrm{CI})\end{array}$} & \multicolumn{2}{|c|}{ Shot at by someone in the neighborhood } & \multicolumn{2}{|c|}{$\begin{array}{l}\text { Witness a violent death in the previous } \\
\text { year }\end{array}$} & \multicolumn{2}{|c|}{$\begin{array}{l}\text { Close family member or friend has been } \\
\text { murdered }\end{array}$} \\
\hline & $\begin{array}{l}\text { Model } 1, \text { OR } \\
(95 \% \mathrm{CI})\end{array}$ & $\begin{array}{l}\text { Model 2, OR } \\
(95 \% \mathrm{CI})\end{array}$ & $\begin{array}{l}\text { Model } 1, \text { OR } \\
(95 \% \mathrm{CI})\end{array}$ & $\begin{array}{l}\text { Model 2, OR } \\
(95 \% \mathrm{CI})\end{array}$ & $\begin{array}{l}\text { Model } 1, \text { OR } \\
(95 \% \mathrm{CI})\end{array}$ & $\begin{array}{l}\text { Model 2, OR } \\
(95 \% \mathrm{CI})\end{array}$ \\
\hline \multicolumn{7}{|c|}{$\begin{array}{l}\text { Area-level covariates } \\
\text { Income inequality }\end{array}$} \\
\hline 1.00 & 1.00 & 1.00 & 1.00 & 1.00 & 1.00 & 1.00 \\
\hline $\begin{array}{l}.76(.32-1.84) \\
\text { Economic depriv }\end{array}$ & $.69(.29-1.67)$ & $.69(.24-1.97)$ & $1.24(.95-1.62)$ & $1.64(1.11-2.42)$ & $1.09(.84-1.42)$ & $1.31(.73-2.36)$ \\
\hline 1.00 & 1.00 & 1.00 & 1.00 & 1.00 & 1.00 & 1.00 \\
\hline $.26(.10-0.70)$ & $.61(.23-1.61)$ & $.61(.23-1.60)$ & $1.30(.83-2.02)$ & $1.32(.84-2.06)$ & $1.34(.70-2.57)$ & $1.35(.69-2.65)$ \\
\hline \multicolumn{7}{|l|}{ Danger } \\
\hline 1.00 & 1.00 & 1.00 & 1.00 & 1.00 & 1.00 & 1.00 \\
\hline $1.00(.36-2.82)$ & $1.84(.87-3.89)$ & $1.84(.87-3.88)$ & $1.15(.83-1.59)$ & $1.15(.82-1.61)$ & $1.69(.92-3.12)$ & $1.66(.88-3.13)$ \\
\hline \multicolumn{7}{|l|}{ Disorder } \\
\hline 1.00 & 1.00 & 1.00 & 1.00 & 1.00 & 1.00 & 1.00 \\
\hline $.81(.26-2.58)$ & $.58(.21-1.60)$ & $.59(.21-1.60)$ & $.67(.42-1.06)$ & $.66(.42-1.05)$ & $.74(.37-1.50)$ & $.75(.36-1.56)$ \\
\hline $\begin{array}{l}1.97(.69-5.67) \\
\text { Proportion black }\end{array}$ & $.62(.22-1.75)$ & $.62(.22-1.75)$ & $.57(.33-0.97)$ & $.55(.32-0.94)$ & $.92(.37-2.29)$ & $.92(.36-2.37)$ \\
\hline 1.00 & 1.00 & 1.00 & 1.00 & 1.00 & 1.00 & 1.00 \\
\hline $2.20(.50-9.67)$ & $.63(.21-1.84)$ & $.62(.21-1.83)$ & $1.17(.74-1.85)$ & $1.15(.71-1.85)$ & $1.32(.87-1.99)$ & $1.32(.87-1.99)$ \\
\hline $5.68(1.11-29.25)$ & $1.53(.39-6.02)$ & $1.52(.38-6.05)$ & $3.06(1.74-5.39)$ & $2.98(1.67-5.34)$ & $2.23(1.41-3.53)$ & $2.20(1.39-3.49)$ \\
\hline \multicolumn{7}{|c|}{ Individual-level covariates } \\
\hline 1.00 & 1.00 & 1.00 & 1.00 & 1.00 & 1.00 & 1.00 \\
\hline $.50(.23-1.06)$ & $1.49(.74-3.00)$ & $1.49(.65-3.43)$ & $.86(.60-1.23)$ & $1.03(.67-1.57)$ & $1.93(1.29-2.89)$ & $2.15(1.42-3.26)$ \\
\hline $.5(.16-1.58)$ & & $1.00(.23-4.35)$ & & $.58(.33-0.99)$ & & $.67(.28-1.59)$ \\
\hline 1.00 & 1.00 & 1.00 & 1.00 & 1.00 & 1.00 & 1.00 \\
\hline $.92(.44-1.90)$ & $1.18(.54-2.60)$ & $1.18(.54-2.59)$ & $.38(.16-0.87)$ & $1.01(.70-1.47)$ & $.73(.53-1.02)$ & $.74(.53-1.02)$ \\
\hline $1.31(.44-1.90)$ & $.57(.14-2.42)$ & $.57(.14-2.39)$ & $1.01(.70-1.46)$ & $.37(.16-0.87)$ & $.24(.12-0.46)$ & $.24(.12-0.45)$ \\
\hline Age, years & & & & & & \\
\hline 1.00 & 1.00 & 1.00 & 1.00 & 1.00 & 1.00 & 1.00 \\
\hline $3.15(.70-14.28)$ & $2.64(.67-10.36)$ & $2.64(.68-10.30)$ & $1.54(.61-3.90)$ & $1.54(.61-3.89)$ & $1.67(.87-3.22)$ & $1.68(.87-3.25)$ \\
\hline $.83(.15-4.67)$ & $.92(.26-3.19)$ & $.92(.27-3.16)$ & $2.02(.77-5.30)$ & $2.00(.76-5.23)$ & $1.81(1.09-2.99)$ & $1.80(1.09-2.99)$ \\
\hline $1.83(.50-6.75)$ & $.90(.25-3.29)$ & $.90(.25-3.27)$ & $1.94(.83-4.51)$ & $1.93(.84-4.48)$ & $1.41(.82-2.43)$ & $1.41(.82-2.43)$ \\
\hline $2.94(.53-16.28)$ & $1.48(.44-5.03)$ & $1.48(.44-4.99)$ & $1.79(.66-4.83)$ & $1.78(.66-4.80)$ & $1.92(.98-3.79)$ & $1.92(.97-3.81)$ \\
\hline $5.41(.52-55.93)$ & $3.53(.51-24.68)$ & $3.53(.51-24.45)$ & $1.92(.59-6.19)$ & $1.78(.56-5.73)$ & $3.18(1.19-8.49)$ & $3.07(1.17-8.06)$ \\
\hline
\end{tabular}

$\mathrm{CI}=$ confidence interval; $\mathrm{OR}=$ odds ratio

reduce the stress [36]. Aggression has also been shown to be a maladaptive way for boys to cope with stress [35]. Committing acts of aggression and violence might be ways in which boys deal with stressful comparisons stemming from income inequality.

An unexpected finding from our study is that although income inequality appeared to be detrimental to nonblack adolescents, income inequality was observed to be protective for aggression and violence among blacks. A possible explanation is that racial residential segregation confounds the association between income inequality and violence in neighborhoods where black youth reside. In other words, African-American families are segregated into high-poverty neighborhoods where income inequality is kept artificially low (because all the households are equally poor). The same neighborhoods also suffer from a higher burden of violence. By contrast, the "high income inequality" neighborhoods where black youth reside may be more racially integrated.

In neighborhoods that are desegregated, or have low proportions of African-Americans, black boys may be more likely to be provoked into aggressive acts when living in close proximity to their nonblack neighbors. Unfortunately, we were limited in the number of neighborhoods in the BYS and lacked power to conduct analyses stratified by race, sex, and segregation and/or proportion of the neighborhood that was African-American.

Our findings should be interpreted in light of limitations of this study. First, cross-sectional data were used for this investigation, therefore the temporal order of income inequality and the aggression outcomes could not be confirmed. However, our study hypotheses and directionality have intuitive appeal and are based on previous work. Second, we used self-report for the aggression and violence outcomes. Therefore, some misclassification is possible, which was likely non-differential and therefore tends to drive the estimates toward the null. Because individual-level covariates, such as household income or parental education, were not collected by the BYS, residual confounding might be an issue. Since these individual-level variables were not collected, we therefore had to use neighborhood-level socioeconomic score. Also, the Baron and Kenny method of mediation assessment might lead to biased results because unknown confounding may exist between mediator and outcome [37,38]. Finally, these results might only be generalizable to urban centers similar to Boston. 


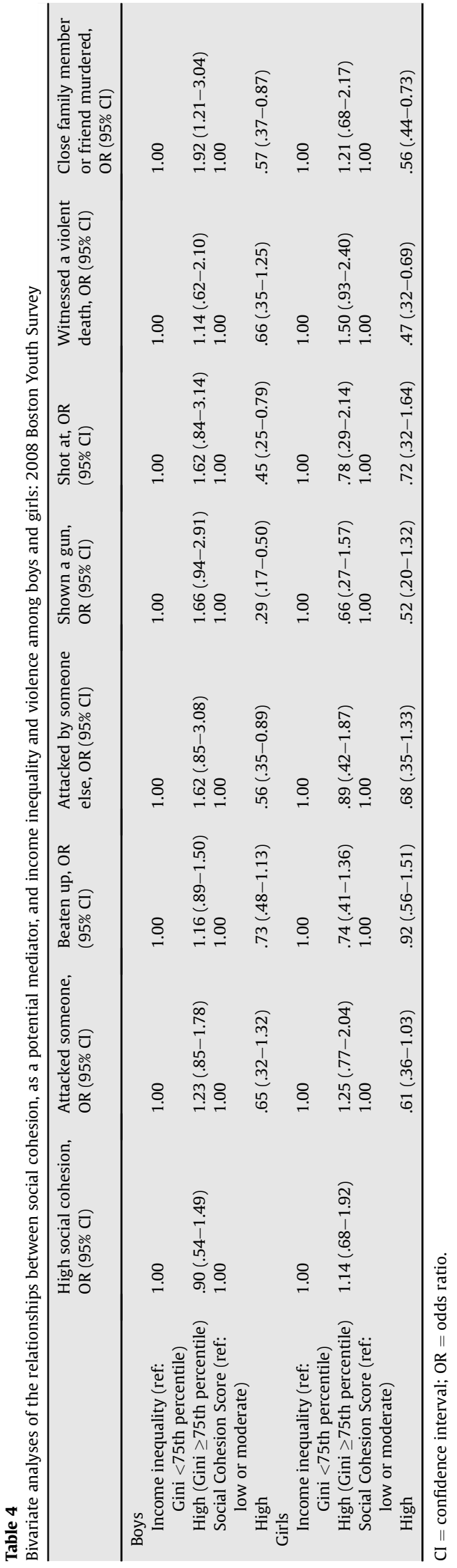

Future directions include conducting cohort studies to confirm the temporal sequence of neighborhood inequality and aggression and violence outcomes and to determine this relationship across time. Because we were limited in the number of neighborhoods, a larger sample size of both students and neighborhoods is needed to fully test segregation-income interaction effects.

In conclusion, findings from this study suggest that income inequality is associated with aggression and violence among adolescents living in an urban setting. Income inequality is potentially detrimental to the development and well-being of all adolescents living within a residential area. Future work needs to use longitudinal data to determine more conclusively whether income inequality is a determinant of aggression and violence.

\section{Acknowledgments}

The Boston Youth Survey was conducted in collaboration with the Boston Public Health Commission (Barbara Ferrer, Executive Director), Boston's Office of Human Services (Larry Mayes, Chief), Boston Public Schools (Carol Johnson, Superintendent), and the Office of The Honorable Mayor Thomas M. Menino. The survey would not have been possible without the participation of the faculty, staff, administrators, and students of Boston Public Schools.

\section{Funding Sources}

This work was supported by a grant from the Center for Disease Control and Prevention National Center for Injury Prevention and Control (U49CE00740) to the Harvard Youth Violence Prevention Center (David Hemenway, Principal Investigator).

\section{References}

[1] Satcher D. Violence as a public health issue. Bull N Y Acad Med 1995;72: 46-56.

[2] Powell EC, Sheehan KM, Christoffel KK. Firearm violence among youth: Public health strategies for prevention. Ann Emerg Med 1996;28:204-12.

[3] Finkelhor D, Ormrod R, Turner H, Hamby SL. The victimization of children and youth: A comprehensive, national survey. Child Maltreat 2005;10: $5-25$.

[4] Clark C, Ryan L, Kawachi I, et al. Witnessing community violence in residential neighborhoods: A mental health hazard for urban women. J Urban Health 2008:85:22-38.

[5] Dowdell EB. Urban seventh grade students: A report of health risk behaviors and exposure to violence. J Sch Nurs 2012;28:130-7.

[6] DuRant RH, Kahn J, Beckford PH, Woods ER. The association of weapon carrying and fighting on school property and other health risk and problem behaviors among high school students. Arch Pediatr Adolesc Med 1997; 151:360-6.

[7] Orpinas PK, Basen-Engquist K, Grunbaum JA, Parcel GS. The co-morbidity of violence-related behaviors with health-risk behaviors in a population of high school students. J Adolesc Health 1995;16:216-25.

[8] Zinzow HM, Ruggiero KJ, Hanson RF, et al. Witnessed community and parental violence in relation to substance use and delinquency in a national sample of adolescents. J Trauma Stress 2009;22:525-33.

[9] Brady SS. Lifetime community violence exposure and health risk behavior among young adults in college. J Adolesc Health 2006;39:610-3.

[10] Morenoff JD, Sampson RJ, Raudenbush SW. Neighborhood inequality, collective efficacy, and the spatial dynamics of urban violence. Criminology 2006;39:517-58.

[11] Massey DS. Getting away with murder: Segregation and violent crime in urban America. Univ Pa L Rev 1995;143:1203.

[12] Kennedy BP, Kawachi I, Prothrow-Stith D, et al. Social capital, income inequality, and firearm violent crime. Soc Sci Med 1998;47:7-17.

[13] Kennedy BP, Kawachi I, Prothrow-Stith D. Income distribution and mortality: Cross sectional ecological study of the Robin Hood index in the United States. BMJ 1996;312:1004-7. 
[14] Kawachi I, Kennedy BP, Wilkinson RG. Crime: Social disorganization and relative deprivation. Soc Sci Med 1999;48:719-31.

[15] Kawachi I, Kennedy BP. The health of nations: Why inequality is harmful to your health. New York: New Press; 2002.

[16] Butchart A, Engstrom K. Sex- and age-specific relations between economic development, economic inequality and homicide rates in people aged 0-24 years: A cross-sectional analysis. Bull World Health Organ 2002;80: 797-805.

[17] Elgar FJ, Craig W, Boyce W, et al. Income inequality and school bullying: Multilevel study of adolescents in 37 countries. J Adolesc Health 2009;45: 351-9.

[18] Last J. A dictionary of epidemiology. 5th edition. New York: Oxford University Press; 2008

[19] Merton RK. Social theory and social structure. New York, NY: Free Press; 1968.

[20] Buka SL, Stichick TL, Birdthistle I, Earls FJ. Youth exposure to violence: Prevalence, risks, and consequences. Am J Orthopsychiatry 2001;71: $298-310$.

[21] Selner-O'Hagan MB, Kindlon DJ, Buka SL, et al. Assessing exposure to violence in urban youth. I Child Psychol Psychiatry 1998;39:215-24.

[22] Stafford M, Cummins S, Macintyre S, et al. Gender differences in the associations between health and neighbourhood environment. Soc Sci Med 2005;60:1681-92.

[23] Pickett KE, Pearl M. Multilevel analyses of neighbourhood socioeconomic context and health outcomes: A critical review. J Epidemiol Community Health 2001;55:111-22.

[24] Rothman EF, Johnson RM, Azrael D, et al. Perpetration of physical assault against dating partners, peers, and siblings among a locally representative sample of high school students in Boston, Massachusetts. Arch Pediat Adolesc Med 2010;164:1118-24.

[25] Hemenway D, Barber CW, Gallagher SS, Azrael DR. Creating a national violent death reporting system: A successful beginning. Am J Prev Med 2009;37:68-71.
[26] Azrael D, Johnson RM, Molnar BE, et al. Creating a youth violence data system for Boston, Massachusetts. Aust N Z J Criminol 2009;42:406-21.

[27] Brennan RT, Molnar BE, Earls F. Refining the measurement of exposure to violence (ETV) in urban youth. J Community Psychol 2007:35:603-19.

[28] Sampson RJ, Raudenbush SW, Earls F. Neighborhoods and violent crime: A multilevel study of collective efficacy. Science 1997;277:918-24.

[29] Rothman EF, Johnson RM, Young R, et al. Neighborhood-level factors associated with physical dating violence perpetration: Results of a representative survey conducted in Boston, MA. J Urban Health 2011;88: $201-13$.

[30] Diez-Roux AV. Multilevel analysis in public health research. Annu Rev Public Health 2000;21:171-92.

[31] Baron RM, Kenny DA. The moderator-mediator variable distinction in social psychological research: Conceptual, strategic, and statistical considerations. J Pers Soc Psychol 1986;51:1173-82.

[32] Wilkinson RG, Pickett KE. Income inequality and population health: A review and explanation of the evidence. Soc Sci Med 2006;62:1768-84.

[33] Hampel P, Petermann F. Age and gender effects on coping in children and adolescents. J Youth Adolesc 2005;34:73-83.

[34] Eschenbeck $H$, Kohlmann CW, Lohaus A Gender differences in coping strategies in children and adolescents. J individual differences 2007;28: $18-26$.

[35] Hampel P, Kummel U, Meier M, et al. [Gender and developmental effects on perceived stress, coping, somatic symptoms and psychological disorders among children and adolescents]. Prax Kinderpsychol Kinderpsychiatr 2005; 54:87-103.

[36] Mattlin JA, Wethington E, Kessler RC. Situational determinants of coping and coping effectiveness. J Health Soc Behav 1990;31:103-22.

[37] Kaufman JS, Maclehose RF, Kaufman S. A further critique of the analytic strategy of adjusting for covariates to identify biologic mediation. Epidemiol Perspect Innov 2004;1:4

[38] Cole SR, Hernan MA. Fallibility in estimating direct effects. Int J Epidemio 2002;31:163-5. 